\title{
Proteomic Analysis of Normal and Cancer Cervical Cell Lines Reveals Deregulation of Cytoskeleton-associated Proteins
}

\author{
KALLIOPI I. PAPPA ${ }^{1,2}$, VASILIKI LYGIROU ${ }^{3,4}$, GEORGIA KONTOSTATHI ${ }^{3,4}$, \\ JEROME ZOIDAKIS ${ }^{3}$, MANOUSOS MAKRIDAKIS ${ }^{3}$, KONSTANTINOS VOUGAS $^{3}$, \\ GEORGE DASKALAKIS ${ }^{1}$, ALEXANDER POLYZOS ${ }^{5}$ and NICHOLAS P. ANAGNOU ${ }^{2,4}$ \\ ${ }^{1}$ First Department of Obstetrics and Gynecology, \\ University of Athens School of Medicine, Alexandra Hospital, Athens, Greece; \\ ${ }^{2}$ Cell and Gene Therapy Laboratory, Centre of Basic Research II, \\ Biomedical Research Foundation of the Academy of Athens (BRFAA), Athens, Greece; \\ ${ }^{3}$ Biotechnology Division, Centre of Basic Research, \\ Biomedical Research Foundation of the Academy of Athens (BRFAA), Athens, Greece; \\ ${ }^{4}$ Laboratory of Biology, University of Athens School of Medicine, Athens, Greece; \\ ${ }^{5}$ Institute of Molecular Biology, Genetics and Biotechnology, \\ Biomedical Research Foundation of the Academy of Athens (BRFAA), Athens, Greece
}

\begin{abstract}
Background: Both HPV-positive and -negative cervical cancers are primarily associated with features of cell cycle and cytoskeletal disruption; however, the actual biological processes affected remain elusive. To this end, we systematically characterized the intracellular proteomic profiles of four distinct and informative cervical cell lines. Materials and Methods: Cell extracts from a normal cervical (HCKIT) and three cervical cancer cell lines, one HPVnegative (C33A), and two HPV-positive, SiHa (HPV16+) and HeLa (HPVI8+), were analyzed by 2-dimensional electrophoresis and differentially expressed proteins were identified by MALDI-TOF mass spectrometry, while differential expression was confirmed by western blot analysis. Results: In total, 113 proteins were found differentially expressed between the normal and the cervical cancer lines. Bioinformatics analysis revealed the actin cytoskeleton signaling pathway to be significantly affected, while up-regulation of cofilin-1, an actin depolymerizing factor, was documented and further validated by western blotting. Furthermore, two-way comparisons among the four
\end{abstract}

This article is freely accessible online.

Correspondence to: Kalliopi I. Pappa, MD, Ph.D., First Department of Obstetrics and Gynecology, University of Athens School of Medicine, Athens, Greece. Tel: +30 210722 7117, Fax: +30 210 6560 308, e-mail: kalliopi.pappa20@ gmail.com

Key Words: Cervical cancer, Cervical cell lines, HCK1T cell line, Proteomics, 2-DE, Cofilin-1. cell lines, revealed a set of 18 informative differentially expressed proteins. Conclusion: These novel identified proteins provide the impetus for further functional studies to dissect the mechanisms operating in the two distinct pathways of cervical carcinogenesis.

Cervical cancer represents the fourth most common and fatal form of cancer among women worldwide (1). More than $90 \%$ of cervical cancer cases arise as a consequence of a human papilloma virus (HPV) infection. Currently, 210 different HPV types have been officially recognized (2), and - based on their carcinogenic potential - have been classified either as low-risk HPV types, or as high-risk and potentially carcinogenic (3). Of the high-risk group, the five most common HPV types include HPV 16, 18, 45, 30, and 33, while types 16 and 18 alone, account for about $70 \%$ of all cervical cancer cases (4).

In the early phase of cervical carcinogenesis, HPV initially infects the proliferating cells of the basal layer of the cervical stratified epithelium through abrasions of the mucosal epithelium. Following infection, the HPV genome remains in the form of nuclear extrachromosomal episome, and due to the repression of the viral E6 and E7 oncoprotein synthesis, the viral DNA replication occurs at very low levels (5). Following the gradual differentiation of the basal cells and their migration to the upper layers of the epithelium, an increased expression of E6 and E7 oncoproteins occurs, leading to inhibition of apoptosis, while the viral genome is replicated further. At this point, structural proteins and mature viral particles are produced, and the shed virus can then initiate a new infection. These 
infections resolve within 1-2 years, but they can last up to several decades. However, very few of them are persistent and gradually progress to cancer (6), reflecting a dynamic interplay of viral mechanisms of immune escape and suppression of the negative regulators of the cell growth, combined with defects of cellular response by the host (5). The final events of the neoplastic transformation are associated frequently (45-80\%) with the integration of the HPV DNA into the host genome and the ensuing overexpression of E6 and E7 oncoproteins, leading to further proliferation of the transformed cells.

Since both HPV-positive and HPV-negative cervical cancers are primarily associated with features of cell-cycle and cytoskeletal disruption (5), the precise elucidation of the contribution of the putative individual oncogenic drivers induced by the presence or the absence of HPV in cervical cancer is imperative. Therefore, utilization of informative cell lines with or without the HPV genome, can provide valuable insights on these mechanisms. To this end, our group has initiated a comprehensive approach to elucidate the specific oncogenic drivers operating in cervical cancer, both at the transcriptional (7) and the proteomic level (8). In these studies, we have identified for the first time, four novel transcription modules (7), involved in cervical cancer, exhibiting synergy between groups of transcription regulators, while certain modules were annotated to specific biological processes, such as cell cycle, apoptosis, transcription and development. In our recent study (8), by employing proteomic approaches on the secretome of four informative cervical cell lines, we have identified 67 differentially expressed proteins, displaying mainly catalytic, binding or structural molecule activity, while bioinformatics analysis identified the transcription factor NRF2 as an important regulator of differentially expressed proteins in the cancer cell lines. Thus, such comparative proteomic approaches employing cervical cell lines, represent a valuable tool to further explore the precise mechanisms involved in viral infection and protein dysfunction interplay that can lead to cervical carcinogenesis $(5,6)$. Furthermore, a review (6) of recent studies on the proteomics of cervical cancer cell lines, revealed that their major focus relies either on the variable effects of several drugs or on the modulation of a specific gene expression on their proteome composition.

Therefore, based on the above data, in the present study, we further investigated these mechanisms, by employing 2dimensional electrophoresis (2-DE) and bioinformatics analysis, and systematically characterized the intracellular proteomic profiles of four distinct informative cervical cell lines, either with or without the presence of HPV, and identified specific biochemical similarities and differences, reflecting particular aberrant pathways of carcinogenesis, which can be eventually validated further and assessed as putative biomarkers of cervical pathology.

\section{Materials and Methods}

Cell lines culture and sample preparation. HeLa (HPV 18+), SiHa (HPV 16+) and C33A (HPV-negative) cervical cancer cell lines, were purchased from ATCC (Manassas, VA, USA) and cultured in Dulbecco's Modified Eagle Medium (DMEM) supplemented with $10 \%$ Fetal Bovine Serum (FBS) (Gibco-Invitrogen, Waltham, MA, USA) at $37^{\circ} \mathrm{C}, 5 \% \mathrm{CO}_{2}$ as previously described (9). HCK1T cells were a kind offer of Tohru Kiyono (10) and were cultured as proposed (11) in Defined Keratinocyte Serum-Free Medium (SFM) (Gibco BRL, San Francisco, CA, USA) supplemented with $5 \mathrm{ng} / \mathrm{ml}$ Epidermal Growth Factor (EGF) (Gibco BRL) and $50 \mu \mathrm{g} / \mathrm{ml}$ of Bovine Pituitary Extract (BPE) (Gibco BRL). When the cells reached a concentration of 106 cells per $\mathrm{ml}$, they were trypsinized and harvested, and the pellets were washed in Phosphate Buffered Saline (PBS) 3 times.

Pellets were homogenized in 2D-Buffer (7 M Urea, $2 \mathrm{M}$ thiourea, $4 \%$ CHAPS, $1 \%$ DTE) using mild sonication (water bath sonication). After centrifugation at $16,000 \times g$ for $20 \mathrm{~min}$, the total cell extract was obtained as a supernatant. Protein concentration was measured with the Bradford assay.

$2 D$ Electrophoresis. From each cell extract, $80 \mu \mathrm{g}$ were loaded on 7-cm immobilized $\mathrm{pH}$ gradient (IPG) strips of $\mathrm{pH}$ 3-10 NL (BioRad, Hercules, CA, USA) in isoelectric focusing (IEF) cell trays, following the addition of $2 \%$ Bio-Lyte 3/10 Ampholytes for isoelectric focusing. For the preparative gels only, the amount of protein loaded from each cell line was $400 \mu \mathrm{g}$. IEF was performed in Bio-Rad PROTEAN IEF cell for 14,000 VHR as follows. Step 1: $50 \mathrm{~V}$, rapid, $14 \mathrm{~h}$ (active rehydration); step 2: $250 \mathrm{~V}$, rapid, 30 min; step 3: 4,000 V, linear, $1 \mathrm{~h}$; step 4: $4000 \mathrm{~V}$, rapid, $11000 \mathrm{VHR}$ (focusing); step 5: $100 \mathrm{~V}$, rapid, $24 \mathrm{~h}$ (conservation). For the second dimension electrophoresis, the equilibration of the strips and the reduction and alkylation of the proteins were performed in equilibration buffer (6 M Urea, 1.5 M Tris $\mathrm{HCl}, \mathrm{pH} 8.8,30 \%$ Glycerol, 2\% SDS) containing $0.03 \mathrm{M}$ DTE for $20 \mathrm{~min}$ and then in equilibration buffer containing $0.136 \mathrm{M}$ Iodoacetamide for $20 \mathrm{~min}$. Strips were then sealed with agarose on top of a $12 \%$ SDSpolyacrylamide gel, which was run at $80 \mathrm{~V}$ for $10 \mathrm{~min}$ and then at 160 V. Following electrophoresis, the gels were fixed in $30 \%$ methanol, $10 \%$ acetic acid for $30 \mathrm{~min}, 2 \mathrm{~h}$ and then overnight. Visualization of the spots was achieved with silver staining. Each gel was sensitized in $0.8 \mathrm{mM}$ sodium thiosulfate pentahydrate solution for $1 \mathrm{~min}$, washed with ultrapure water for $1 \mathrm{~min}$, stained in $12 \mathrm{mM}$ silver nitrate solution for $20 \mathrm{~min}$ and washed again with ultrapure water for $10 \mathrm{sec}$. Visualization of the spots was performed with $50 \mathrm{ml}$ of development solution $(3 \% \mathrm{w} / \mathrm{v}$ potassium carbonate, $12.5 \mu \mathrm{l}$ formalin-formaldehyde $37 \%, 5.25 \mu \mathrm{l} 10 \% \mathrm{w} / \mathrm{v}$ sodium thiosulfate pentahydrate). When the development was completed, the gel was washed with ultrapure water for $10 \mathrm{sec}$ and the stop solution ( $2 \%$ acetic acid) was added and left for $10 \mathrm{~min}$. After two washes with ultrapure water for $10 \mathrm{~min}$, the gels were scanned with a GS-800 imaging densitometer (Bio-Rad). Four 2D gels from each cell line were prepared and were used for the analysis.

Comparative analysis. The comparative analysis of the 2D gels images was performed with the PDQuest 2D-Gel analysis software v.8.1.0 (Bio-Rad). The individual protein spot quantity was normalized with the total optical density of the gel. All protein spots with a cancer/normal ratio $<0.5$ or $>2$ were considered as differentially expressed and were included for further analysis. 
Spot preparation and protein identification. The spots were picked manually from the corresponding preparative 2D gels, which were stained with Coomassie Colloidal Blue overnight, placed in 96-well plates, and $100 \mu \mathrm{l}$ of destaining solution $(40 \% \mathrm{ACN}, 50 \mathrm{mM}$ ammonium bicarbonate) was added in each spot. The plates were shaken for $15 \mathrm{~min}$ and this step was repeated three times. Then, the spots were washed with $100 \mu \mathrm{l}$ ultrapure water for $5 \mathrm{~min}$, reduced with $100 \mu \mathrm{l}$ of $10 \mathrm{mM}$ DTE dissolved in $100 \mathrm{mM}$ ammonium bicarbonate, $\mathrm{pH} 8.5$ for $10 \mathrm{~min}$ and alkylated with $100 \mu \mathrm{l}$ of $54 \mathrm{mM}$ iodoacetamide, dissolved in $100 \mathrm{mM}$ ammonium bicarbonate, $\mathrm{pH}$ 8.5 for $10 \mathrm{~min}$ in the dark. The spots were washed with $100 \mu \mathrm{l}$ of $100 \mathrm{mM}$ ammonium bicarbonate, $\mathrm{pH} 8.5$ for $5 \mathrm{~min}$ and then dried in a Savant SpeedVac ${ }^{\mathrm{TM}}$ concentrator (Thermo Fisher Scientific, Logan, UT, USA). Finally, $3 \mu \mathrm{l}$ of $10 \mathrm{ng} / \mu \mathrm{l}$ trypsin in $10 \mathrm{mM}$ ammonium bicarbonate was added, and left overnight. The products of tryptic digestion were extracted from the gel by the addition of $5 \mu \mathrm{l}$ of extraction solution ( $50 \% \mathrm{ACN}, 0.1 \% \mathrm{TFA}$ ) for $30 \mathrm{~min}$. Then, $1 \mu \mathrm{l}$ of peptides from each spot were mixed on a stainless steel MALDI target plate with $1 \mu \mathrm{l}$ of matrix solution $(50 \% \mathrm{v} / \mathrm{v} \mathrm{ACN}$, $0.1 \%$ TFA v/v, $0.7 \% \mathrm{v} / \mathrm{v} \quad \alpha$-cyano-4-hydroxycinnamic acid) containing the peptides des-Arg-bradykinin, 904.4681Da (SigmaAldrich Corp., St. Louis, MO, USA), and the adrenocorticotropic hormone fragment 18-39, 2465.1989Da (Sigma-Aldrich), as internal standards. For peptide identification, Matrix Assisted Laser Desorption Ionization-Time of Flight/Time of Flight Mass Spectrometry (MALDI-TOF/TOF MS) was performed in an Ultraflex TOF/TOF mass spectrometer (Bruker Daltonics, Billerica, MA, USA). Peak list was created with the Flexanalysis v2.2 software (Bruker Daltonics), peptide matching and protein searches were performed automatically by Mascot Server database (Matrix Science, Boston, MA, USA), signal/noise threshold ratio was set at 2.5. For peptide identification, monoisotopic masses were used and a mass tolerance of $0.0025 \%$ (25 ppm) was allowed. Cysteine carbamidomethylation and methionine oxidation were set as fixed and variable modifications, respectively. One miscleavage was allowed. The peptide masses were compared with the theoretical peptide masses of all available proteins from Homo sapiens using the Swiss-Prot database. The probability score with $p<0.05$ identified by the software, was used as the criterion for the affirmative protein identification.

Bioinformatics analysis. Functional annotation of the differentially expressed proteins was performed manually using information from UniProt (http://www.uniprot.org/) and the literature. Pathway analysis was generated by QIAGEN's Ingenuity ${ }^{\circledR}$ Pathway Analysis (IPA ${ }^{\circledR}$, QIAGEN, Redwood City, CA, USA; www.qiagen.com/ ingenuity). Ingenuity ${ }^{\circledR}$ Pathway Analysis output was manually curated in order to remove redundant terms, results unrelated to cancer biology, and pathways with fewer than three differentially expressed proteins from our dataset. Moreover, only statistically significant ( $p \leq 0.05$, Fisher's exact test) canonical pathways were selected.

Western blot analysis. Four $50 \mu \mathrm{g}$ samples of cell extract dissolved in Laemli's buffer from each cell line were loaded in 15\% SDSpolyacrylamide gel after incubation at $90^{\circ} \mathrm{C}$ for $10 \mathrm{~min}$. The gel was run at $40 \mathrm{~V}$ for $15 \mathrm{~min}$ and then at $120 \mathrm{~V}$ in transfer buffer (3.03 g Tris, $14.4 \mathrm{~g}$ Glycine, $200 \mathrm{ml}$ Methanol for 1 liter total volume). The transfer was performed in transfer buffer for $2 \mathrm{~h}$ at $290 \mathrm{~mA}$ at $4^{\circ} \mathrm{C}$. Then, the membrane was stained with Ponceau-S stain for $5 \mathrm{~min}$, washed with ultrapure water for $5 \mathrm{~min}$ three times, followed by the addition of blocking solution (5\% w/v non-fat dried milk in TBS-Tween $0.1 \% \mathrm{v} / \mathrm{v}$ ) and incubation for $2 \mathrm{~h}$. The membrane was washed with TBS-Tween $0.1 \% \mathrm{v} / \mathrm{v}$ successively for $15 \mathrm{~min}, 5 \mathrm{~min}$, and $5 \mathrm{~min}$, and the primary mouse antibody sc53934 for Cofilin-1 (Santa Cruz Biotechnology, Inc., Dallas, TX, USA) was added in a 1:500 dilution and left at $4^{\circ} \mathrm{C}$ overnight. The next day, the three washes were repeated and the secondary sc2005 goat anti-mouse antibody IgG-HRP (Santa Cruz Biotechnology) was added in a 1:2,000 dilution and left at room temperature for $2 \mathrm{~h}$. The three washes were repeated, ECL was added and left for $1 \mathrm{~min}$; its excess was removed, followed by film exposure and development.

\section{Results}

Proteomic analysis. In order to investigate the quantitative differences in protein expression resulting from malignant transformation of the cervical epithelium, the proteomic profiles of four cervical cell lines were analyzed. The four cell lines that were used were the following: HCK1T (Human Cervical Keratinocytes), a normal cervical epithelium cell line; HeLa, a cervical cancer cell line positive for HPV18; $\mathrm{SiHa}$, a cervical cancer cell line positive for HPV16; and C$33 \mathrm{~A}$, a cervical cancer cell line negative for HPV. Four 2D gels were run for each cell line total extract. A representative gel is shown in Figure 1 for each cell line. The initial analysis was focused on the comparison between the normal cervical cell line (HCK1T) and the group of the three cervical cancer cell lines (HeLa, SiHa, C-33A). In this comparison, 43 spots, that corresponded to 48 unique proteins, were found downregulated (cancer/normal ratio $<0.5$ ) in the cancer cell lines. Almost half of these proteins $(42 \%)$, are associated to cytoskeleton and $21 \%$ of them are involved in metabolism (Figure 2). Moreover, 85 spots, that corresponded to 65 unique proteins, were found up-regulated (cancer/normal ratio $>2$ ) in the cancer cell lines. A significant percentage of these proteins are also associated to cytoskeleton (8\%) and metabolism (42\%) (Figure 2). Proteins that were found deregulated included cofilin-1; vinculin; vimentin; fascin; annexin A2; transgelin-2; alpha-enolase; triosephosphate isomerase; glyceraldehyde-3-phosphate dehydrogenase; peptidyl-prolyl cis-trans isomerase A; fructose-bisphosphate aldolase A; peroxiredoxins 1, 2, 5 and 6; protein DJ-1; and growth factor receptor-bound protein 2 . A complete list of the differentially expressed proteins is presented in Table I.

The overlap of differentially expressed proteins among the three comparisons was examined and is presented in a Venn diagram in Figure 3. Five proteins only emerged from the comparison between the HPV-negative cervical cancer cell line (C-33A) and the normal cervical keratinocytes (HCK1T), while 13 proteins composed the HPV-positive "core", emerging from the individual comparisons between the HPV-positive cervical cancer cell lines (HeLa and $\mathrm{SiHa}$ ) with the HCK1T (Table II). 

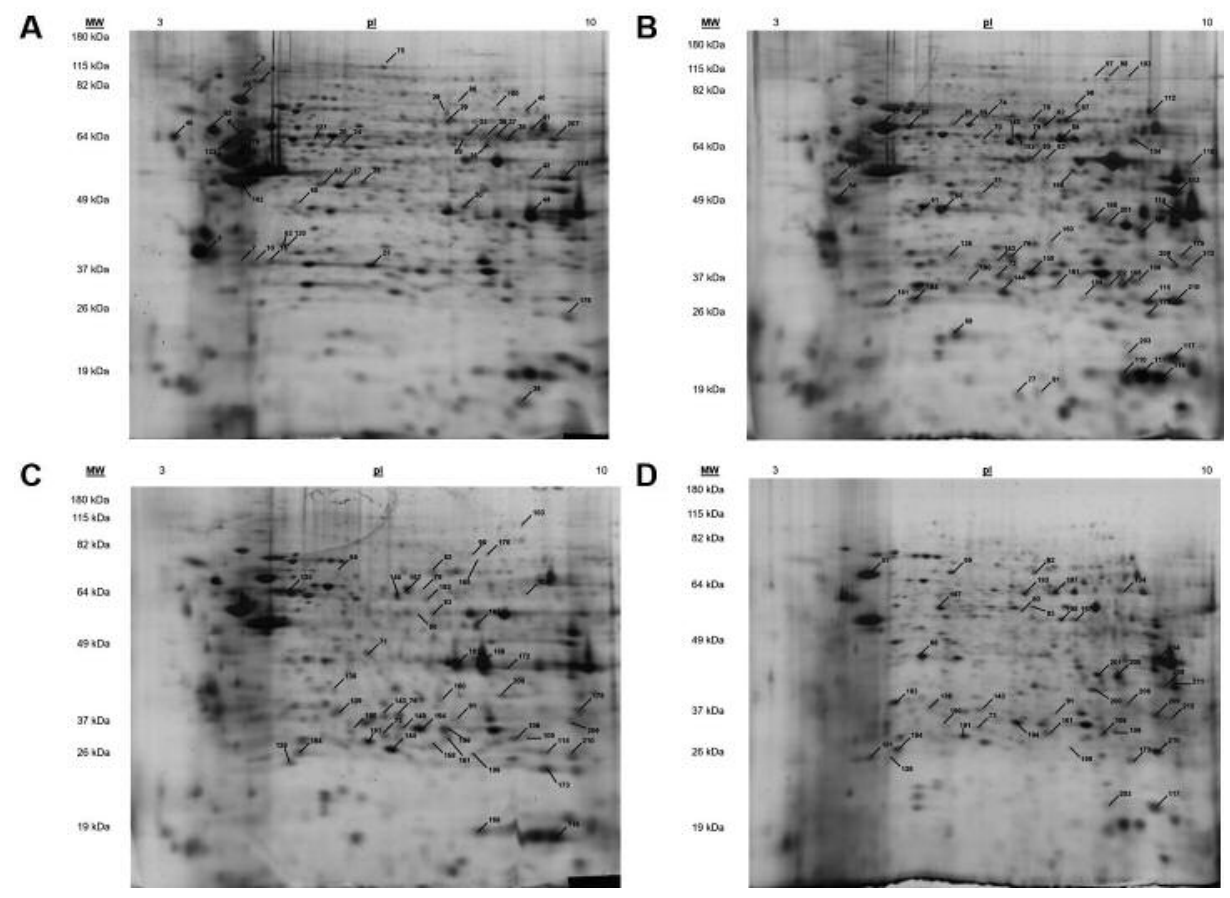

Figure 1. Annotated 2D gel images of cervical cell lines with differentially expressed proteins between normal and cancer states. A. HCK1T cell extract. The annotated proteins were found up-regulated in HCK1T (normal cervical epithelium) in comparison with the cancer cell lines. B. HeLa cell extract. The annotated proteins were found up-regulated in HeLa in comparison with HCKIT. C. SiHa cell extract. The annotated proteins were found up-regulated in SiHa in comparison to HCK1T. D. C-33A cell extract. The annotated proteins were found up-regulated in C-33A in comparison to HCKIT. The numbers of the spots correspond to proteins listed in Table I.

Bioinformatics analysis. Pathway analysis of the differentially expressed proteins between the normal (HCK1T) and the three cancer (HeLa, SiHa, C-33A) cell lines, using the Ingenuity ${ }^{\circledR}$ Pathway Analysis (IPA) software, revealed that the actin cytoskeleton signaling pathway is associated in a statistically significant manner $(p=0.029)$ (Figures 4 and 5, Table III). As mentioned previously, biological function annotation also documented that a large percentage of all the differentially expressed proteins, are associated to cytoskeleton. Based on these indications, and the known biological contribution to cancer pathogenesis, proteins involved in cytoskeletal processes were further investigated. Thus, cofilin-1 (CFL1), an actin depolymerizing factor (ADF) that is implicated in aggressive cancer cell behavior (12-17), was selected for further validation. The main function of cofilin-1 is the depolymerization of F-actin, a biological process crucial for normal mitosis, cytokinesis and cell migration (18). Cofilin1 , was actually up-regulated in all three cancer cell lines (Table I).

Confirmation of the proteomic analysis results. In the 2D gels, cofilin-1 was found up-regulated in HeLa and C-33A cell lines (HeLa/HCK1T ratio: 3.6, C-33A/HCK1T ratio: 3.0). Its levels were also higher in $\mathrm{SiHa}$ compared to the ones in HCK1T, but did not reach the 2-fold threshold (SiHa/HCK1T ratio: 1.3) as shown in Figure 6A. The upregulation of cofilin-1 in the $2 \mathrm{D}$ gels was confirmed by western blot analysis on the four cell lines (Figure 6B). As shown in Figure 6, the levels of cofilin-1 in the western blot analysis follow the same expression pattern as in the $2 \mathrm{D}$ gels, thus confirming the proteomic analysis results.

\section{Discussion}

The comparison of proteomic profiles between the three cervical cancer cell lines (HeLa, SiHa, C-33A) and the normal cervical keratinocytes (HCK1T) total cell extract, revealed a total of 113 differentially expressed proteins (cancer/normal ratio $<0.5$ or $>2$ ). Around $60 \%$ of these proteins are associated to cytoskeleton or metabolism. Moreover, bioinformatics analysis of the differentially expressed proteins revealed that actin cytoskeleton signaling represents a statistically significant pathway deregulated in cervical cancer. This finding led us to the investigation of cofilin-1, in the context of cervical cancer 
A

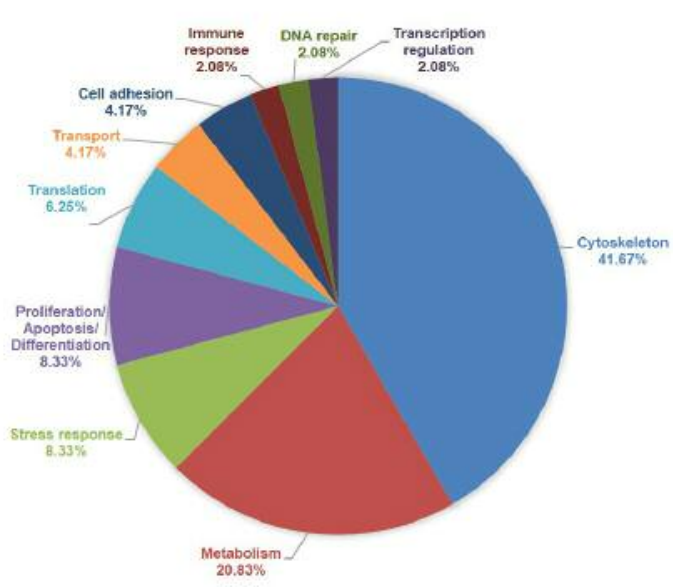

B

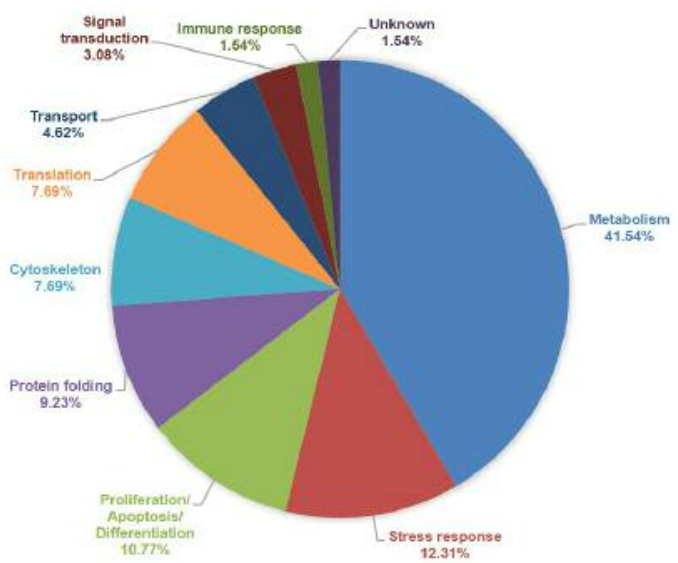

Figure 2. Functional annotation of the differentially expressed proteins from the comparison between normal and cancer cervical cell lines. A. Functional annotation of the proteins found down-regulated in cancer cell lines compared to normal. B. Functional annotation of the proteins found up-regulated in the cancer cell lines compared to normal.

and actin cytoskeleton remodeling, and the independent confirmation of its expression trend by western blot analysis.

Functional annotation of the differentially expressed proteins indicated that nearly $63 \%$ of all deregulated proteins are involved in metabolism. More specifically, $67 \%$ of the proteins involved in metabolism are up-regulated in the cervical cancer cell lines compared to normal cervical keratinocytes. This finding could serve as a validation of our approach, since uncontrolled proliferation occurring during carcinogenesis, generates additional anabolic and energy demands. To sustain survival and proliferation, cancer cells have to activate or enhance metabolic pathways that utilize the available nutrients for production of metabolic precursors for cell anabolism, and maintain the reduction-oxidation balance (19). Hence, molecules and regulators that

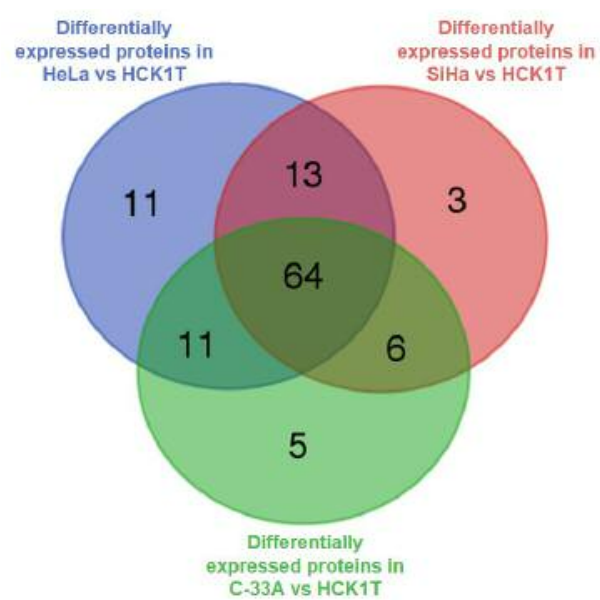

Figure 3. Venn diagram of the differentially expressed proteins in the three individual comparisons. Differentially expressed proteins in HeLa vs. HCK1T; SiHa vs. HCK1T; and C-33A vs. HCK1T, are represented with the blue, red and green circles, respectively. Five proteins are unique in the comparison of the HPV-negative cell line (C-33A) to the normal cervical keratinocytes (HCK1T), and 13 proteins are common between the comparisons of the HPV-positive cell lines (HeLa and $\mathrm{SiHa}$ ) to HCK1T, while not present in the comparison between C-33A vs. HCK1T.

participate in such metabolic processes are expected to be deregulated in cancer cells when compared to normal ones. Such typical examples of enzyme proteins that emerged from our analysis, included alpha-enolase; triosephosphate isomerase; glyceraldehyde-3-phosphate dehydrogenase; peptidyl-prolyl cis-trans isomerase $\mathrm{A}$; fructose-bisphosphate aldolase A; and peroxiredoxins 1, 2, 5 and 6 .

Actin cytoskeleton signaling, a statistically significant pathway that emerged from bioinformatics analysis of the differentially expressed proteins, is known to play a pivotal role in cancer, since actin cytoskeleton remodeling is essential for cell proliferation and migration. The process, during which a cancer cell migrates from the original site of the tumor to a new site, consists of specific steps, known as the 'metastatic cascade'. To metastasize, a cancer cell has to detach from the primary tumor site, migrate, intravasate, translocate through vessels, extravasate, and finally, attach and grow a secondary tumor at a new site. Due to their plasticity, cancer cells can move utilizing either mesenchymal or amoeboid motility, depending on the physical properties of the extracellular matrix, the degree of extracellular proteolysis and on the soluble signaling factors. This whole procedure requires extensive cell cytoskeleton reorganization to achieve the desired cell movements and shape alterations. Actin cytoskeleton remodeling requires the fine orchestration among actin microfilaments, intermediate filaments and microtubules $(20,21)$. 
Table I. List of differentially expressed proteins following comparison between normal and cancer cervical cell lines.

A. Proteins down-regulated in the cervical cancer cell lines compared to normal cervical keratinocytes (HCK1T).

\begin{tabular}{|c|c|c|c|c|c|c|c|c|}
\hline \multirow[t]{2}{*}{ Spot \# } & \multirow[t]{2}{*}{ Uniprot ID } & \multirow[t]{2}{*}{ Protein } & \multirow{2}{*}{$\begin{array}{l}\text { Mascot } \\
\text { score }\end{array}$} & \multirow{2}{*}{$\begin{array}{l}\text { Molecular } \\
\text { weight } \\
\text { (Da) }\end{array}$} & \multirow[t]{2}{*}{$\mathrm{pI}$} & \multicolumn{3}{|c|}{$\begin{array}{l}\text { Expression } \\
\text { fold change }\end{array}$} \\
\hline & & & & & & $\begin{array}{l}\text { HeLa/ } \\
\text { HCK1T }\end{array}$ & $\begin{array}{c}\mathrm{SiHa} / \\
\mathrm{HCK} 1 \mathrm{~T}\end{array}$ & $\begin{array}{l}\text { C-33A/ } \\
\text { HCK1T }\end{array}$ \\
\hline 3 & 1433S_HUMAN & 14-3-3 protein sigma & 91 & 27871 & 4,5 & 0,145 & 0,246 & 0,082 \\
\hline 6 & VIME_HUMAN & Vimentin & 161 & 53676 & 4,9 & 0,461 & & N/A \\
\hline 7 & HSPB1_HUMAN & Heat shock protein beta-1 & 78 & 22826 & 6,0 & & 0,324 & 0,376 \\
\hline 8 & TERA_HUMAN & Transitional endoplasmic reticulum ATPase & 57 & 89950 & 5,0 & & 0,284 & 0,065 \\
\hline \multirow[t]{2}{*}{9} & HSP7C_HUMAN & Heat shock cognate $71 \mathrm{kDa}$ protein & 81 & 71082 & 5,2 & 0,429 & & 0,330 \\
\hline & HSP71_HUMAN & Heat shock $70 \mathrm{kDa}$ protein $1 \mathrm{~A} / 1 \mathrm{~B}$ & 85 & 70294 & 5,4 & & & \\
\hline 10 & HSPB1_HUMAN & Heat shock protein beta-1 & 119 & 22826 & 6,0 & 0,353 & 0,269 & \\
\hline 15 & HSPB1_HUMAN & Heat shock protein beta-1 & 85 & 22826 & 6,0 & 0,134 & 0,071 & 0,127 \\
\hline 17 & SPB5_HUMAN & Serpin B5 & 65 & 42530 & 5,7 & 0,356 & 0,132 & 0,123 \\
\hline 20 & HNRH1_HUMAN & Heterogeneous nuclear ribonucleoprotein $\mathrm{H}$ & 85 & 49484 & 5,9 & 0,383 & & \\
\hline 22 & CAPG_HUMAN & Macrophage-capping protein & 51 & 38760 & 5,8 & & & 0,201 \\
\hline 23 & HSPB1_HUMAN & Heat shock protein beta-1 & 131 & 22826 & 6,0 & 0,260 & 0,381 & 0,023 \\
\hline 24 & K2C6A_HUMAN & Keratin, type II cytoskeletal $6 \mathrm{~A}$ & 49 & 60293 & 8,9 & 0,176 & & 0,380 \\
\hline 28 & WDR1_HUMAN & WD repeat-containing protein 1 & 76 & 66836 & 6,2 & & 0,287 & 0,468 \\
\hline 29 & PUR9_HUMAN & Bifunctional purine biosynthesis protein PURH & 80 & 65089 & 6,3 & & & 0,404 \\
\hline 30 & PDLI1_HUMAN & PDZ and LIM domain protein 1 & 187 & 36505 & 6,6 & & & $\mathrm{~N} / \mathrm{A}$ \\
\hline \multirow[t]{2}{*}{33} & K2C5_HUMAN & Keratin, type II cytoskeletal 5 & 120 & 62568 & 8,6 & & & 0,101 \\
\hline & FSCN1_HUMAN & Fascin & 103 & 55123 & 7,0 & & & \\
\hline \multirow[t]{4}{*}{35} & FSCN1_HUMAN & Fascin & 159 & 55123 & 7,0 & 0,452 & 0,420 & \\
\hline & K2C6A_HUMAN & Keratin, type II cytoskeletal 6A & 95 & 60293 & 8,9 & & & \\
\hline & K2C6B_HUMAN & Keratin, type II cytoskeletal 6B & 87 & 60315 & 8,9 & & & \\
\hline & K2C6C_HUMAN & Keratin, type II cytoskeletal $6 \mathrm{C}$ & 75 & 60273 & 8,9 & & & \\
\hline \multirow[t]{2}{*}{36} & FSCN1_HUMAN & Fascin & 237 & 55123 & 7,0 & 0,200 & 0,091 & 0,058 \\
\hline & TRIP6_HUMAN & Thyroid receptor-interacting protein 6 & 59 & 51738 & 8,0 & & & \\
\hline 37 & K2C5_HUMAN & Keratin, type II cytoskeletal 5 & 97 & 62568 & 8,6 & 0,164 & 0,129 & 0,224 \\
\hline \multirow[t]{3}{*}{38} & K2C6A_HUMAN & Keratin, type II cytoskeletal 6A & 98 & 60293 & 8,9 & 0,032 & 0,019 & 0,044 \\
\hline & K2C6B_HUMAN & Keratin, type II cytoskeletal 6B & 88 & 60315 & 8,9 & & & \\
\hline & K2C6C_HUMAN & Keratin, type II cytoskeletal 6C & 75 & 60273 & 8,9 & & & \\
\hline 39 & ISG15_HUMAN & Ubiquitin-like protein ISG15 & 78 & 17933 & 7,8 & 0,118 & 0,173 & 0,162 \\
\hline 40 & TKT_HUMAN & Transketolase & 108 & 68519 & 8,5 & & 0,314 & \\
\hline \multirow[t]{4}{*}{41} & K2C5_HUMAN & Keratin, type II cytoskeletal 5 & 146 & 62568 & 8,6 & & & 0,244 \\
\hline & K2C6A__HUMAN & Keratin, type II cytoskeletal 6A & 143 & 60293 & 8,9 & & & \\
\hline & K2C6B_HUMAN & Keratin, type II cytoskeletal 6B & 124 & 60315 & 8,9 & & & \\
\hline & K2C6C_HUMAN & Keratin, type II cytoskeletal 6C & 111 & 60273 & 8,9 & & & \\
\hline 42 & KCRU_HUMAN & Creatine kinase U-type, mitochondrial & 60 & 47406 & 9,4 & 0,324 & 0,457 & \\
\hline \multirow[t]{2}{*}{44} & ANXA2_HUMAN & Annexin A2 & 141 & 38808 & 8,5 & 0,440 & & 0,044 \\
\hline & AXA2L_HUMAN & Putative annexin A2-like protein & 66 & 38806 & 6,6 & & & \\
\hline 46 & CALR_HUMAN & Calreticulin & 188 & 48283 & 4,1 & & 0,447 & \\
\hline 52 & PDIA1_HUMAN & Protein disulfide-isomerase & 143 & 57480 & 4,6 & & & 0,140 \\
\hline 55 & GRP78_HUMAN & $78 \mathrm{kDa}$ glucose-regulated protein & 105 & 72402 & 4,9 & & & 0,305 \\
\hline 60 & EIF3I_HUMAN & Eukaryotic translation initiation factor 3 subunit I & 113 & 36878 & 5,3 & & 0,499 & \\
\hline 62 & XRCC5_HUMAN & $\mathrm{X}$-ray repair cross-complementing protein 5 & 63 & 83222 & 5,5 & & & 0,369 \\
\hline 63 & RLA0_HUMAN & $60 \mathrm{~S}$ acidic ribosomal protein $\mathrm{P} 0$ & 114 & 34423 & 5,6 & & & 0,401 \\
\hline 75 & VINC_HUMAN & Vinculin & 63 & 124292 & 5,4 & & & 0,125 \\
\hline 86 & ACTG_HUMAN & Actin, cytoplasmic 2 & 53 & 42108 & 5,2 & & & 0,336 \\
\hline \multirow[t]{2}{*}{89} & IMDH2_HUMAN & Inosine-5'-monophosphate dehydrogenase 2 & 89 & 56226 & 6,5 & & 0,199 & 0,284 \\
\hline & FSCN1_HUMAN & Fascin & 64 & 55123 & 7,0 & & & \\
\hline 100 & FUBP1_HUMAN & Far upstream element-binding protein 1 & 81 & 67690 & 7,8 & & & 0,478 \\
\hline \multirow[t]{3}{*}{120} & HSP71_HUMAN & Heat shock $70 \mathrm{kDa}$ protein 1A/1B & 159 & 70294 & 5,4 & & & 0,369 \\
\hline & GRP75_HUMAN & Stress-70 protein, mitochondrial & 124 & 73920 & 5,8 & & & \\
\hline & HSP76_HUMAN & Heat shock $70 \mathrm{kDa}$ protein 6 & 66 & 71440 & 5,8 & & & \\
\hline 123 & TBB5_HUMAN & Tubulin beta chain & 122 & 50095 & 4,6 & & & N/A \\
\hline & TBB2C_HUMAN & Tubulin beta-2C chain & 111 & 50255 & 4,7 & & & \\
\hline & ATPB_HUMAN & ATP synthase subunit beta, mitochondrial & 106 & 56525 & 5,1 & & & \\
\hline & TBB4_HUMAN & Tubulin beta- 4 chain & 101 & 50010 & 4,6 & & & \\
\hline
\end{tabular}


Table I. Continued

\begin{tabular}{|c|c|c|c|c|c|c|c|c|}
\hline \multirow[t]{2}{*}{ Spot \# } & \multirow[t]{2}{*}{ Uniprot ID } & \multirow[t]{2}{*}{ Protein } & \multirow{2}{*}{$\begin{array}{c}\text { Mascot } \\
\text { score }\end{array}$} & \multirow{2}{*}{$\begin{array}{l}\text { Molecular } \\
\text { weight } \\
\text { (Da) }\end{array}$} & \multirow[t]{2}{*}{$\mathrm{pI}$} & \multicolumn{3}{|c|}{$\begin{array}{l}\text { Expression } \\
\text { fold change }\end{array}$} \\
\hline & & & & & & $\begin{array}{l}\text { HeLa/ } \\
\text { HCK1T }\end{array}$ & $\begin{array}{l}\mathrm{SiHa} / \\
\mathrm{HCK} 1 \mathrm{~T}\end{array}$ & $\begin{array}{l}\text { C-33A/ } \\
\text { HCK1T }\end{array}$ \\
\hline & TBB2A_HUMAN & Tubulin beta-2A chain & 101 & 50274 & 4,6 & & & \\
\hline 127 & K2C8_HUMAN & Keratin, type II cytoskeletal 8 & 81 & 53671 & 5,4 & 0,159 & & N/A \\
\hline 162 & K1C19_HUMAN & Keratin, type I cytoskeletal 19 & 277 & 44079 & 4,9 & 0,007 & 0,003 & N/A \\
\hline 174 & PGK1_HUMAN & Phosphoglycerate kinase 1 & 149 & 44985 & 9,2 & & & 0,419 \\
\hline 176 & TAGL2_HUMAN & Transgelin-2 & 144 & 22548 & 9,3 & 0,255 & & $\mathrm{~N} / \mathrm{A}$ \\
\hline \multirow[t]{5}{*}{179} & ATPB_HUMAN & ATP synthase subunit beta, mitochondrial & 167 & 56525 & 5,1 & 0,465 & & \\
\hline & TBB5_HUMAN & Tubulin beta chain & 64 & 50095 & 4,6 & & & \\
\hline & TBB2B_HUMAN & Tubulin beta-2B chain & 58 & 50377 & 4,6 & & & \\
\hline & TBB2A_HUMAN & Tubulin beta- $2 \mathrm{~A}$ chain & 58 & 50274 & 4,6 & & & \\
\hline & PDIA6_HUMAN & Protein disulfide-isomerase A6 & 55 & 48490 & 4,8 & & & \\
\hline \multirow[t]{2}{*}{207} & ATPA_HUMAN & ATP synthase subunit alpha, mitochondrial & 107 & 59828 & 9,6 & 0,344 & 0,412 & \\
\hline & GLYM_HUMAN & Serine hydroxymethyltransferase, mitochondrial & 70 & 56414 & 9,5 & & & \\
\hline
\end{tabular}

B. Proteins up-regulated in the cancer cervical cell lines compared to normal cervical keratinocytes (HCK1T).

\begin{tabular}{|c|c|c|c|c|c|c|c|c|}
\hline 53 & RSSA_HUMAN & 40 S ribosomal protein $\mathrm{SA}$ & 55 & 32947 & 4,6 & 2,480 & & \\
\hline 54 & EF1D_HUMAN & Elongation factor 1-delta & 51 & 31217 & 4,8 & 11,990 & & \\
\hline 57 & CH60_HUMAN & $60 \mathrm{kDa}$ heat shock protein, mitochondrial & 187 & 61187 & 5,6 & 2,430 & & 2,380 \\
\hline \multirow[t]{2}{*}{59} & TCPE_HUMAN & T-complex protein 1 subunit epsilon & 73 & 60089 & 5,3 & 4,020 & & \\
\hline & CH60_HUMAN & $60 \mathrm{kDa}$ heat shock protein, mitochondrial & 70 & 61187 & 5,6 & & & \\
\hline 61 & IPYR_HUMAN & Inorganic pyrophosphatase & 109 & 33095 & 5,5 & 2,090 & & \\
\hline 65 & PDIA3_HUMAN & Protein disulfide-isomerase A3 & 200 & 57146 & 5,9 & 3,140 & 2,450 & \\
\hline 66 & LDHB_HUMAN & L-lactate dehydrogenase B chain & 64 & 36900 & 5,7 & 2,280 & & 2,410 \\
\hline 68 & NDKA_HUMAN & Nucleoside diphosphate kinase A & 107 & 17309 & 5,8 & 2,520 & & \\
\hline 69 & TCPA_HUMAN & T-complex protein 1 subunit alpha & 126 & 60819 & 5,7 & 3,580 & & 3,190 \\
\hline \multirow[t]{2}{*}{70} & SBP1_HUMAN & Selenium-binding protein 1 & 152 & 52928 & 5,9 & 3,110 & & \\
\hline & TCPB_HUMAN & T-complex protein 1 subunit beta & 66 & 57794 & 6,0 & & & \\
\hline 71 & ENOA_HUMAN & Alpha-enolase & 78 & 47481 & 7,7 & 2,150 & 2,690 & \\
\hline 73 & TPIS_HUMAN & Triosephosphate isomerase & 113 & 31057 & 5,6 & 3,210 & 3,990 & 2,440 \\
\hline 74 & LMNA_HUMAN & Prelamin-A/C & 112 & 74380 & 6,6 & 6,780 & & \\
\hline 76 & ERP29_HUMAN & Endoplasmic reticulum resident protein 29 & 121 & 29032 & 7,5 & 10,200 & 8,170 & \\
\hline 77 & FABP5_HUMAN & Fatty acid-binding protein, epidermal & 78 & 15497 & 7,5 & 6,340 & & \\
\hline 78 & LMNA_HUMAN & Prelamin-A/C & 101 & 74380 & 6,6 & 3,480 & & \\
\hline 79 & SERA_HUMAN & D-3-phosphoglycerate dehydrogenase & 70 & 57356 & 6,3 & 10,630 & 2,770 & \\
\hline 80 & EF1G_HUMAN & Elongation factor 1-gamma & 138 & 50429 & 6,3 & 7,570 & 2,230 & 5,570 \\
\hline 81 & HINT2_HUMAN & $\begin{array}{l}\text { Histidine triad nucleotide-binding protein } 2, \\
\text { mitochondrial }\end{array}$ & 50 & 17208 & 9,8 & 3,900 & & \\
\hline \multirow[t]{3}{*}{82} & TCPZ_HUMAN & T-complex protein 1 subunit zeta & 66 & 58444 & 6,2 & 5,890 & 2,920 & 2,120 \\
\hline & STIP1_HUMAN & Stress-induced-phosphoprotein 1 & 62 & 63227 & 6,4 & & & \\
\hline & LMNA_HUMAN & Prelamin-A/C & 60 & 74380 & 6,6 & & & \\
\hline 83 & ENOA_HUMAN & Alpha-enolase & 116 & 47481 & 7,7 & 4,600 & 2,430 & 2,180 \\
\hline 87 & STIP1_HUMAN & Stress-induced-phosphoprotein 1 & 93 & 63227 & 6,4 & 3,390 & & \\
\hline 88 & SERA_HUMAN & D-3-phosphoglycerate dehydrogenase & 149 & 57356 & 6,3 & 5,350 & & \\
\hline 91 & PGAM1_HUMAN & Phosphoglycerate mutase 1 & 144 & 28900 & 6,8 & & 2,710 & 3,270 \\
\hline 96 & GUAA_HUMAN & GMP synthase [glutamine-hydrolyzing] & 120 & 77408 & 6,4 & 4,040 & 2,560 & \\
\hline 97 & EF2_HUMAN & Elongation factor 2 & 60 & 96246 & 6,4 & 2,320 & & \\
\hline 98 & EF2_HUMAN & Elongation factor 2 & 118 & 96246 & 6,4 & 5,500 & & \\
\hline 102 & PSA2_HUMAN & Proteasome subunit alpha type- 2 & 95 & 25996 & 7,7 & 2,040 & & \\
\hline 103 & EF2_HUMAN & Elongation factor 2 & 72 & 96246 & 6,4 & 3,050 & 2,090 & \\
\hline 104 & K2C1_HUMAN & Keratin, type II cytoskeletal 1 & 47 & 66170 & 8,8 & 13,780 & 2,460 & 6,530 \\
\hline 107 & GBLP_HUMAN & $\begin{array}{l}\text { Guanine nucleotide-binding protein } \\
\text { subunit beta-2-like } 1\end{array}$ & 177 & 35511 & 8,9 & 4,760 & & \\
\hline 108 & RAN_HUMAN & GTP-binding nuclear protein Ran & 133 & 24579 & 7,8 & 3,550 & 2,600 & 2,470 \\
\hline 109 & HCD2_HUMAN & 3-hydroxyacyl-CoA dehydrogenase type-2 & 145 & 27134 & 9,1 & 8,720 & 5,035 & 4,640 \\
\hline \multirow[t]{2}{*}{110} & PPIA_HUMAN & Peptidyl-prolyl cis-trans isomerase A & 91 & 18229 & 9,0 & 3,060 & & \\
\hline & PRDX5_HUMAN & Peroxiredoxin-5, mitochondrial & 81 & 22301 & 9,9 & & & \\
\hline
\end{tabular}


Table I. Continued

\begin{tabular}{|c|c|c|c|c|c|c|c|c|}
\hline \multirow[t]{2}{*}{ Spot \# } & \multirow[t]{2}{*}{ Uniprot ID } & \multirow[t]{2}{*}{ Protein } & \multirow{2}{*}{$\begin{array}{c}\text { Mascot } \\
\text { score }\end{array}$} & \multirow{2}{*}{$\begin{array}{l}\text { Molecular } \\
\text { weight } \\
\text { (Da) }\end{array}$} & \multirow[t]{2}{*}{$\mathrm{pI}$} & \multicolumn{3}{|c|}{$\begin{array}{l}\text { Expression } \\
\text { fold change }\end{array}$} \\
\hline & & & & & & $\begin{array}{l}\text { HeLa/ } \\
\text { HCK1T }\end{array}$ & $\begin{array}{l}\mathrm{SiHa} / \\
\mathrm{HCK} 1 \mathrm{~T}\end{array}$ & $\begin{array}{l}\text { C-33A/ } \\
\text { HCK1T }\end{array}$ \\
\hline 111 & PPIA_HUMAN & Peptidyl-prolyl cis-trans isomerase A & 113 & 18229 & 9,0 & 2,610 & & \\
\hline 112 & KPYM_HUMAN & Pyruvate kinase isozymes M1/M2 & 258 & 58470 & 9,0 & 4,620 & & \\
\hline 113 & ALDOA_HUMAN & Fructose-bisphosphate aldolase A & 140 & 39851 & 9,2 & 2,520 & & \\
\hline \multirow[t]{2}{*}{114} & LDHA_HUMAN & L-lactate dehydrogenase A chain & 92 & 36950 & 9,3 & 3,940 & & 2,170 \\
\hline & G3P_HUMAN & Glyceraldehyde-3-phosphate dehydrogenase & 91 & 36201 & 9,3 & & & \\
\hline 115 & PRDX1_HUMAN & Peroxiredoxin-1 & 152 & 22324 & 9,2 & 13,960 & 4,640 & \\
\hline 116 & PPIA_HUMAN & Peptidyl-prolyl cis-trans isomerase A & 84 & 18229 & 9,0 & 3,660 & 3,480 & \\
\hline 117 & COF1_HUMAN & Cofilin-1 & 99 & 18719 & 9,1 & 4,670 & & 2,370 \\
\hline 118 & G3P_HUMAN & Glyceraldehyde-3-phosphate dehydrogenase & 52 & 36201 & 9,3 & 2,440 & & \\
\hline 125 & K2C7_HUMAN & Keratin, type II cytoskeletal 7 & 61,00 & 51411 & 5,3 & & 3,350 & \\
\hline 126 & APT_HUMAN & Adenine phosphoribosyltransferase & 94 & 19767 & 5,7 & & 7,510 & 3,350 \\
\hline 138 & RFA2_HUMAN & Replication protein A $32 \mathrm{kDa}$ subunit & 57 & 29342 & 5,7 & & 2,380 & \\
\hline 139 & ERP29_HUMAN & Endoplasmic reticulum resident protein 29 & 61 & 29032 & 7,5 & 2,030 & 7,280 & 2,190 \\
\hline 143 & A26L1_HUMAN & $\begin{array}{l}\text { Putative ankyrin repeat domain-containing } \\
\text { protein } 26 \text {-like } 1\end{array}$ & 47 & 14164 & 9,6 & 3,460 & 13,400 & 14,730 \\
\hline 144 & PARK7_HUMAN & Protein DJ-1 & 93 & 20050 & 6,4 & 2,400 & 8,820 & \\
\hline 145 & TCPB_HUMAN & T-complex protein 1 subunit beta & 112 & 57794 & 6,0 & 2,700 & 2,410 & \\
\hline 148 & LSHB_HUMAN & Lutropin subunit beta & 51 & 16019 & 9,9 & & 2,040 & \\
\hline 152 & SCOT1_HUMAN & $\begin{array}{l}\text { Succinyl-CoA:3-ketoacid-coenzyme A } \\
\text { transferase } 1, \text { mitochondrial }\end{array}$ & 70 & 56578 & 7,8 & 5,990 & 10,220 & \\
\hline 158 & K1C10_HUMAN & Keratin, type I cytoskeletal 10 & 56 & 59020 & 5,0 & 4,370 & 2,800 & \\
\hline 160 & PNPH_HUMAN & Purine nucleoside phosphorylase & 82 & 32325 & 6,5 & 3,890 & 7,810 & \\
\hline 161 & PSA2_HUMAN & Proteasome subunit alpha type- 2 & 67 & 25996 & 7,7 & 10,690 & 30,980 & 25,550 \\
\hline 163 & ALDR_HUMAN & Aldose reductase & 139 & 36230 & 6,6 & & 5,050 & \\
\hline 165 & LSHB_HUMAN & Lutropin subunit beta & 47 & 16019 & 9,9 & & 2,140 & \\
\hline 167 & IDHC_HUMAN & Isocitrate dehydrogenase [NADP] cytoplasmic & 199 & 46915 & 6,6 & & 11,680 & 2,530 \\
\hline 168 & ALDR_HUMAN & Aldose reductase & 172 & 36230 & 6,6 & & 3,730 & 43,060 \\
\hline 169 & PPIA_HUMAN & Peptidyl-prolyl cis-trans isomerase A & 47 & 18229 & 9,0 & 2,860 & & \\
\hline 170 & LSHB_HUMAN & Lutropin subunit beta & 48 & 16019 & 9,9 & 2,920 & & \\
\hline 172 & ALDR_HUMAN & Aldose reductase & 80 & 36230 & 6,6 & 3,260 & & \\
\hline 173 & PEBP1_HUMAN & Phosphatidylethanolamine-binding protein 1 & 82 & 21158 & 7,8 & 3,140 & 8,340 & 3,220 \\
\hline 175 & LEG3_HUMAN & Galectin-3 & 66 & 26193 & 9,1 & 2,270 & 9,860 & \\
\hline 181 & ATP5H_HUMAN & ATP synthase subunit $d$, mitochondrial & 56 & 18537 & 5,1 & 5,310 & & 9,660 \\
\hline 183 & PHB_HUMAN & Prohibitin & 98 & 29843 & 5,5 & & & 11,430 \\
\hline 184 & PRDX2_HUMAN & Peroxiredoxin-2 & 78 & 22049 & 5,6 & 4,940 & 9,490 & 16,010 \\
\hline 187 & CH60_HUMAN & $60 \mathrm{kDa}$ heat shock protein, mitochondrial & 160 & 61187 & 5,6 & & & 5,790 \\
\hline 190 & GRB2_HUMAN & Growth factor receptor-bound protein 2 & 80 & 25304 & 5,9 & 2,290 & 15,090 & 12,680 \\
\hline 191 & PRDX3_HUMAN & $\begin{array}{c}\text { Thioredoxin-dependent peroxide reductase, } \\
\text { mitochondrial }\end{array}$ & 57 & 28017 & 8,9 & & 5,350 & 7,380 \\
\hline 193 & AL7A1_HUMAN & Alpha-aminoadipic semialdehyde dehydrogenase & 56 & 59020 & 9,1 & & 2,280 & 6,190 \\
\hline 194 & RAN_HUMAN & GTP-binding nuclear protein Ran & 65 & 24579 & 7,8 & & 6,210 & 4,530 \\
\hline 196 & TPIS_HUMAN & Triosephosphate isomerase & 84 & 31057 & 5,6 & & 2,050 & \\
\hline 197 & AL7Ā1_HUMAN & Alpha-aminoadipic semialdehyde dehydrogenase & 71 & 59020 & 9,1 & & & 7,110 \\
\hline 198 & EFTU_HUMAN & Elongation factor Tu, mitochondrial & 202 & 49852 & 7,9 & 2,060 & & 3,360 \\
\hline 199 & PSB2_HUMAN & Proteasome subunit beta type- 2 & 61 & 22993 & 6,6 & 5,560 & 4,400 & 10,330 \\
\hline 200 & ETFA_HUMAN & $\begin{array}{c}\text { Electron transfer flavoprotein subunit alpha, } \\
\text { mitochondrial }\end{array}$ & 51 & 35400 & 9,5 & & 2,840 & 3,830 \\
\hline 201 & GBLP_HUMAN & $\begin{array}{l}\text { Guanine nucleotide-binding protein } \\
\text { subunit beta-2-like } 1\end{array}$ & 138 & 35511 & 8,9 & 3,160 & & 12,500 \\
\hline 203 & COF1_HUMAN & Cofilin-1 & 55 & 18719 & 9,1 & 2,430 & & 3,720 \\
\hline 205 & VDAC2̄_HUMAN & Voltage-dependent anion-selective channel protein 2 & 94 & 32060 & 8,7 & & & 6,060 \\
\hline 206 & PSA4_HUMAN & Proteasome subunit alpha type- 4 & 63 & 29750 & 8,7 & & & 2,400 \\
\hline 208 & VDAC1__HUMAN & Voltage-dependent anion-selective channel protein 1 & 89 & 30868 & 9,2 & & & 3,730 \\
\hline 209 & ETFB_HUMAN & Electron transfer flavoprotein subunit beta & 55 & 28054 & 9,2 & 3,120 & 7,850 & 9,950 \\
\hline 210 & PRDX6̄_HUMAN & Peroxiredoxin- 6 & 88 & 25133 & 6,0 & 11,580 & 4,360 & 11,520 \\
\hline 211 & VDAC1_HUMAN & Voltage-dependent anion-selective channel protein 1 & 82 & 30868 & 9,2 & & & 17,930 \\
\hline 212 & PSA7_HUMAN & Proteasome subunit alpha type- 7 & 75 & 28041 & 9,3 & 2,340 & & 4,280 \\
\hline
\end{tabular}


Table II. Differentially expressed proteins that are unique following the comparisons of HPV-negative and HPV-positive cervical cancer cell lines with normal cervical keratinocytes.

\begin{tabular}{|c|c|c|c|c|c|c|}
\hline Uniprot ID & Protein & $\begin{array}{l}\text { Molecular } \\
\text { weight (Da) }\end{array}$ & $\mathrm{pI}$ & Spot & $\begin{array}{c}\text { Mascot } \\
\text { score }\end{array}$ & $\begin{array}{l}\text { C-33A/ } \\
\text { HCK1T }\end{array}$ \\
\hline PDLI1_HUMAN & PDZ and LIM domain protein 1 & 36505 & 6,6 & 30 & 187 & N/A (down) \\
\hline VDAC1_HUMAN & Voltage-dependent anion-selective channel protein 1 & 30868 & 9,2 & $\begin{array}{l}208 \\
211\end{array}$ & $\begin{array}{l}89 \\
82\end{array}$ & $\begin{array}{c}3,730 \\
17,930\end{array}$ \\
\hline VDAC2_HUMAN & Voltage-dependent anion-selective channel protein 2 & 32060 & 8,7 & 205 & 94 & 6,060 \\
\hline PSA4_HUMAN & Proteasome subunit alpha type- 4 & 29750 & 8,7 & 206 & 63 & 2,400 \\
\hline PHB_HUMAN & Prohibitin & 29843 & 5,5 & 183 & 98 & 11,430 \\
\hline
\end{tabular}

B. Proteins common between the comparisons of the HPV-positive cell lines (HeLa and SiHa) to HCK1T, while not present in the comparison between C-33A vs. HCK1T.

\begin{tabular}{|c|c|c|c|c|c|c|c|}
\hline Uniprot ID & Protein & $\begin{array}{l}\text { Molecular } \\
\text { weight (Da) }\end{array}$ & $\mathrm{pI}$ & Spot & $\begin{array}{l}\text { Mascot } \\
\text { score }\end{array}$ & $\begin{array}{l}\text { HeLa/ } \\
\text { HCK1T }\end{array}$ & $\begin{array}{l}\mathrm{SiHa} / \\
\mathrm{HCK} 1 \mathrm{~T}\end{array}$ \\
\hline \multirow[t]{4}{*}{ PPIA_HUMAN } & \multirow[t]{4}{*}{ Peptidyl-prolyl cis-trans isomerase A } & \multirow[t]{4}{*}{18229} & \multirow[t]{4}{*}{9,0} & 110 & 91 & 3,060 & \\
\hline & & & & 111 & 113 & 2,610 & \\
\hline & & & & 116 & 84 & 3,660 & 3,480 \\
\hline & & & & 169 & 47 & & 2,860 \\
\hline GUAA_HUMAN & GMP synthase & 77408 & 6,4 & 96 & 120 & 4,040 & 2,560 \\
\hline K1C10_HUMAN & Keratin, type I cytoskeletal 10 & 59020 & 5,0 & 158 & 56 & 4,370 & 2,800 \\
\hline PRDX1_HUMAN & Peroxiredoxin-1 & 22324 & 9,2 & 115 & 152 & 13,960 & 4,640 \\
\hline PARK7_HUMAN & Protein deglycase DJ-1 & 20050 & 6,4 & 144 & 93 & 2,400 & 8,820 \\
\hline \multirow[t]{3}{*}{ ALDR_HUMAN } & \multirow[t]{3}{*}{ Aldose reductase } & \multirow[t]{3}{*}{36230} & \multirow[t]{3}{*}{6,6} & 163 & 139 & & 5,050 \\
\hline & & & & 168 & 172 & 3,730 & 43,060 \\
\hline & & & & 172 & 80 & & 3,260 \\
\hline LEG3_HUMAN & Galectin-3 & 26193 & 9,1 & 175 & 66 & 2,270 & 9,860 \\
\hline \multirow[t]{2}{*}{ TCPB_HUMAN } & \multirow{2}{*}{ T-complex protein 1 subunit beta } & \multirow[t]{2}{*}{57794} & \multirow[t]{2}{*}{6,0} & 70 & 66 & 3,110 & \\
\hline & & & & 145 & 112 & 2,700 & 2,410 \\
\hline \multirow[t]{2}{*}{ SERA_HUMAN } & \multirow[t]{2}{*}{ D-3-phosphoglycerate dehydrogenase } & \multirow[t]{2}{*}{57356} & \multirow[t]{2}{*}{6,3} & 79 & 70 & 10,630 & 2,770 \\
\hline & & & & 88 & 149 & 5,350 & \\
\hline PDIA3_HUMAN & Protein disulfide-isomerase A3 & 57146 & 5,9 & 65 & 200 & 3,140 & 2,450 \\
\hline SCOT1_HUMAN & $\begin{array}{l}\text { Succinyl-CoA:3-ketoacid coenzyme } \\
\text { A transferase } 1, \text { mitochondrial }\end{array}$ & 56578 & 7,8 & 152 & 70 & 5,990 & 10,220 \\
\hline \multirow[t]{3}{*}{ EF2_HUMAN } & \multirow[t]{3}{*}{ Elongation factor 2} & \multirow[t]{3}{*}{96246} & \multirow[t]{3}{*}{6,4} & 97 & 60 & 2,320 & \\
\hline & & & & 98 & 118 & 5,500 & \\
\hline & & & & 103 & 72 & 3,050 & 2,090 \\
\hline PNPH_HUMAN & Purine nucleoside phosphorylase & 32325 & 6,5 & 160 & 82 & 3,890 & 7,810 \\
\hline
\end{tabular}

In our study, cofilin-1, which is involved in the Actin cytoskeleton signaling, was actually up-regulated in HeLa and C-33A (>2-fold expression change), while it was also found in higher levels in SiHa (1.3-fold expression change) compared to HCK1T. This expression trend was confirmed by western blot analysis on the four cell lines total cell extract, employing an antibody previously validated and recommended for use in western blot, according to the guidelines (22).

Cofilin-1 is a small protein of $\sim 19 \mathrm{kD}$ whose name stands for cofilamentous protein. It plays a key role in actin dynamics, cell division, chemotaxis and cancer cell migration $(18,23)$. Cofilin-
1 severs and depolymerizes actin filaments, thus increasing the free barbed ends where actin polymerization occurs $(24,25)$. However, different concentrations of cofilin-1 have different effects on actin filament severing and nucleation. Low concentration favors severing, while high concentration favors nucleation (26). Cofilin-1 also has a Nuclear Localization Signal (NLS) and can transfer monomeric actin in the nucleus where rod-like structures of actin are formed in response to heat shock, ATP-depletion and dimethyl sulfoxide (DMSO) treatment, cytochalasin D or high cytosolic G-actin concentration. However, its biological role in the nucleus remains unclear (18). 


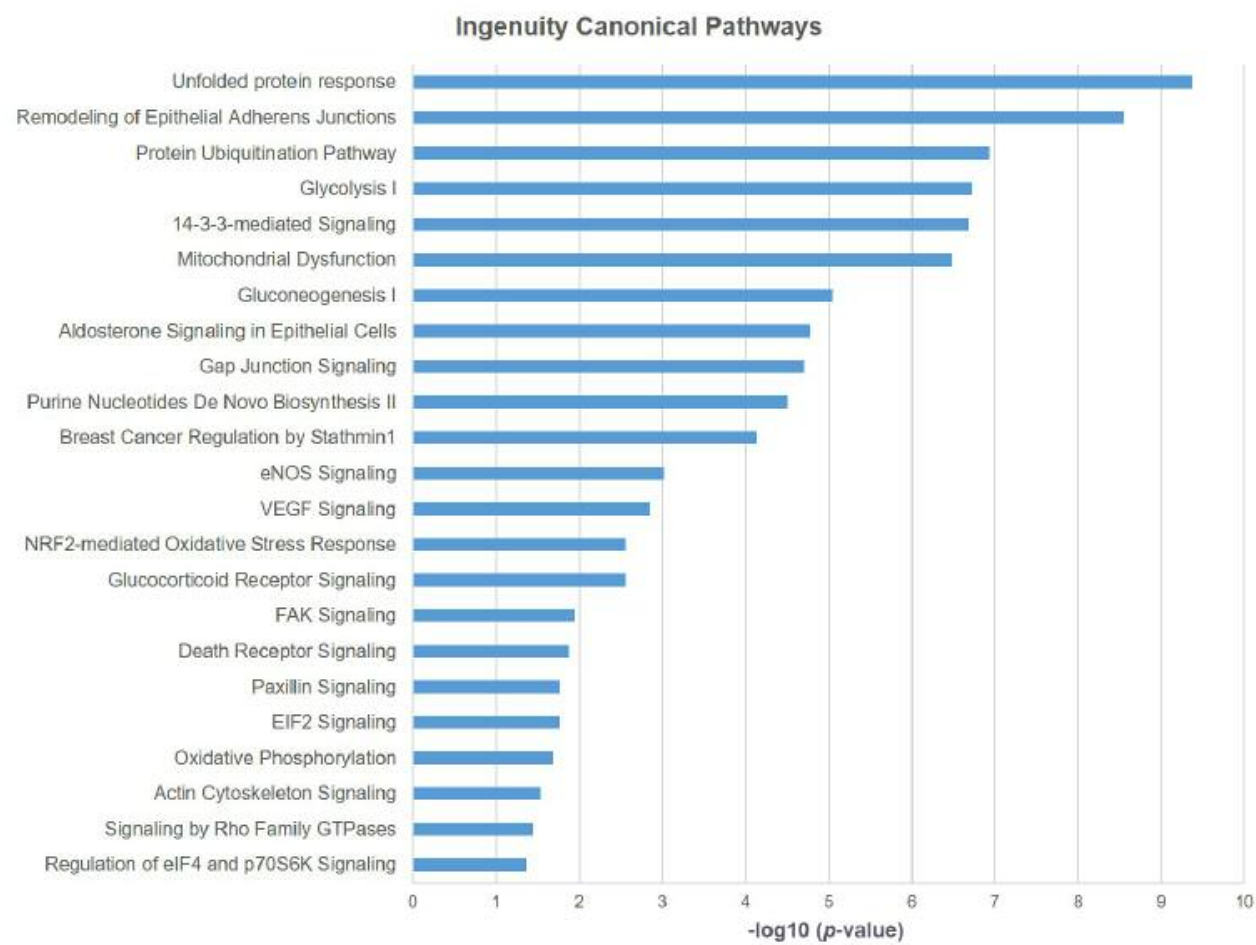

Figure 4. Ingenuity ${ }^{\circledR}$ Canonical Pathways deregulated between normal and cancer cervical cell lines. Only statistically significant pathways are shown in a descending order of p-value using Fisher's exact test.

Table III. List of Ingenuity® Pathway Analysis results from the comparison between normal and cancer cervical cell lines. Only statistically significant pathways are shown in a descending order of p-value, using Fisher's exact test.

\begin{tabular}{lcc}
\hline Ingenuity ${ }^{\circledR}$ Canonical Pathways & $p$-Value & Differentially expressed proteins from our dataset \\
\hline Unfolded protein response & $4.17 \mathrm{E}-10$ & CALR, HSPA1A/HSPA1B, HSPA9, HSPA8, HSPA5, VCP, HSPA6, P4HB \\
Remodeling of Epithelial Adherens Junctions & $2.82 \mathrm{E}-09$ & TUBB2A, TUBB4A, VCL, ACTG1, TUBB, TUBB2B, NME1, TUBB4B \\
Protein Ubiquitination Pathway & $1.17 \mathrm{E}-07$ & HSPB1, HSPA1A/HSPA1B, HSPA9, PSMA4, PSMA7, HSPA8, \\
& & HSPA5, HSPD1, PSMA2, PSMB2, HSPA6 \\
Glycolysis I & $1.91 \mathrm{E}-07$ & TPI1, PGAM1, PGK1, GAPDH, ALDOA \\
14-3-3-mediated Signaling & $2.09 \mathrm{E}-07$ & TUBB2A, VIM, TUBB4A, SFN, TUBB, TUBB2B, GRB2, TUBB4B \\
Mitochondrial Dysfunction & $3.31 \mathrm{E}-07$ & HSD17B10, VDAC1, PARK7, PRDX5, VDAC2, ATP5A1, ATP5H, PRDX3, ATP5B \\
Gluconeogenesis I & $8.91 \mathrm{E}-06$ & PGAM1, PGK1, GAPDH, ALDOA \\
Aldosterone Signaling in Epithelial Cells & $1.70 \mathrm{E}-05$ & HSPB1, HSPA1A/HSPA1B, HSPA9, HSPA8, HSPA5, HSPD1, HSPA6 \\
Gap Junction Signaling & $1.95 \mathrm{E}-05$ & TUBB2A, TUBB4A, ACTG1, TUBB, TUBB2B, GRB2, TUBB4B \\
Purine Nucleotides De Novo Biosynthesis II & $3.09 \mathrm{E}-05$ & IMPDH2, GMPS, ATIC \\
Breast Cancer Regulation by Stathmin1 & $7.41 \mathrm{E}-05$ & TUBB2A, TUBB4A, GNB2L1, TUBB, TUBB2B, GRB2, TUBB4B \\
eNOS Signaling & $9.55 \mathrm{E}-04$ & HSPA1A/HSPA1B, HSPA9, HSPA8, HSPA5, HSPA6 \\
VEGF Signaling & $1.41 \mathrm{E}-03$ & SFN, VCL, ACTG1, GRB2 \\
Glucocorticoid Receptor Signaling & $2.75 \mathrm{E}-03$ & HSPA1A/HSPA1B, HSPA9, HSPA8, HSPA5, GRB2, HSPA6 \\
NRF2-mediated Oxidative Stress Response & $2.75 \mathrm{E}-03$ & ACTG1, ERP29, VCP, PRDX1, STIP1 \\
FAK Signaling & $1.12 \mathrm{E}-02$ & VCL, ACTG1, GRB2 \\
Death Receptor Signaling & $1.32 \mathrm{E}-02$ & HSPB1, ACTG1, LMNA \\
EIF2 Signaling & $1.74 \mathrm{E}-02$ & GRB2, EIF3I, RPLP0, RPSA \\
Paxillin Signaling & $1.74 \mathrm{E}-02$ & VCL, ACTG1, GRB2 \\
Oxidative Phosphorylation & $2.04 \mathrm{E}-02$ & ATP5A1, ATP5H, ATP5B \\
Actin Cytoskeleton Signaling & $2.88 \mathrm{E}-02$ & CFL1, VCL, ACTG1, GRB2 \\
Signaling by Rho Family GTPases & $3.63 \mathrm{E}-02$ & VIM, CFL1, ACTG1, GNB2L1 \\
Regulation of eIF4 and p70S6K Signaling & $4.37 \mathrm{E}-02$ & GRB2, EIF3I, RPSA \\
\hline
\end{tabular}




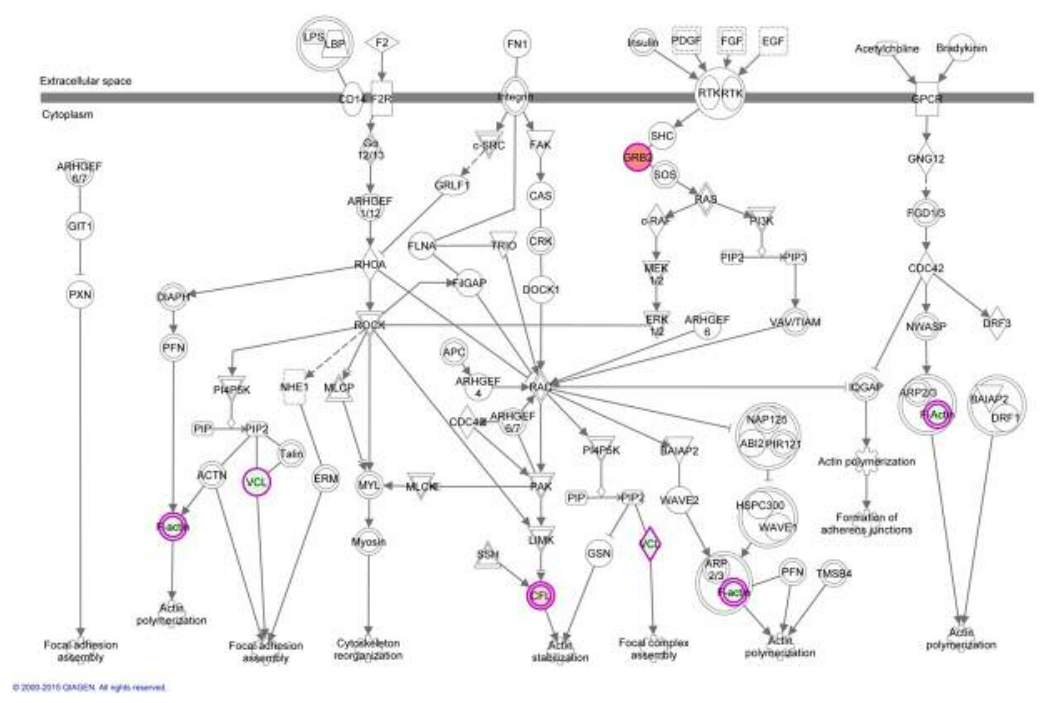

Figure 5. Actin cytoskeleton signaling is a statistically significant affected pathway in cervical cancer cells, as documented from the Ingenuity ${ }^{\circledR}$ Pathway Analysis of the differentially expressed proteins, between cervical cancer cell lines and normal cervical keratinocytes. Nodes filled with red color represent proteins that were found up-regulated in cervical cancer cell lines and nodes filled with green color represent proteins that were found down-regulated in the cervical cancer cell lines. Double-lined nodes represent groups of proteins or complexes.

A

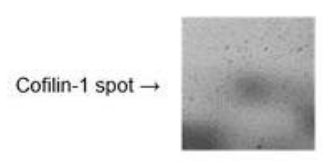

HCK1T

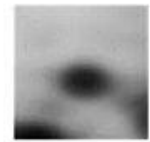

HeLa

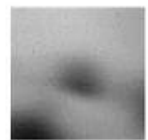

SiHa

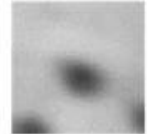

C-33A

B

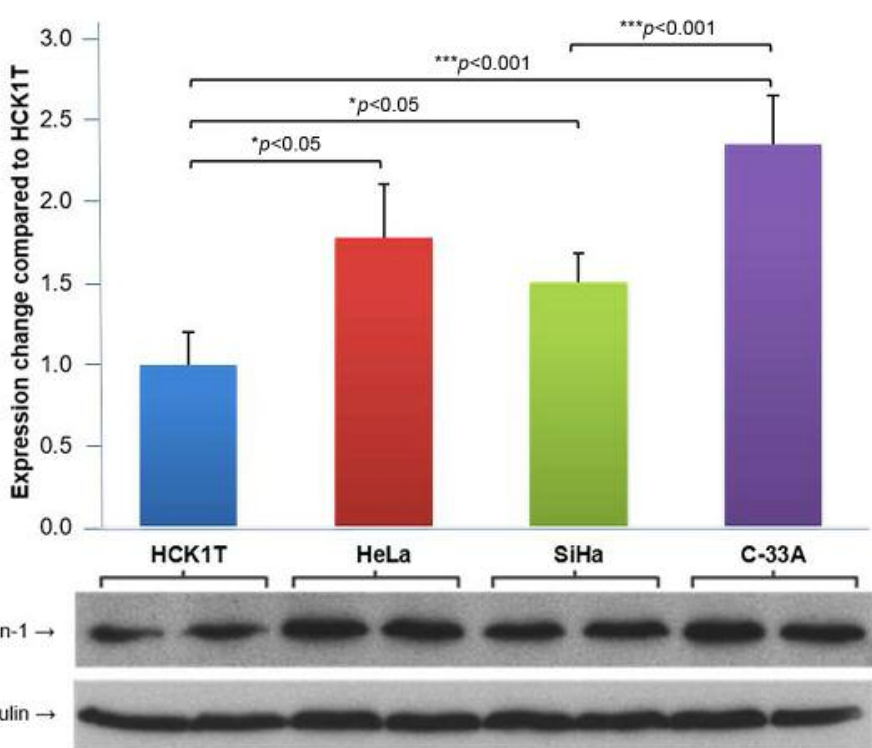

Figure 6. Cofilin-1 levels in cervical cell lines. A. Cofilin-1 levels in proteomics analysis. Fold change is expressed in comparison with HCK1T, as the average from the two identified spots on $2 D$ gels, measured with PDQuest software. B. Cofilin-1 levels in western blot analysis. Fold change is expressed in comparison with HCKIT representing the average from four biological replicates for each cell line, measured with the Quantity One 1-D Analysis software (Bio-Rad). Tubulin levels were used for signal normalization in western blots. Mean values and standard deviation bars are shown for each cell line, and p-value was calculated with Student's t-test. 
The function of cofilin-1 does not only depend on its concentration, but also on several environmental factors. Phosphorylated cofilin- 1 on ser- 3 is considered to be inactive because of its lower affinity for actin. LIM kinase 1 (LIMK1), LIM kinase 2 (LIMK2) and testicular protein kinase 1/2 (TESK1/2) phospohorylate cofilin-1 on ser3, while slingshot-1L (SSH1L) phosphatase and chronophin (CIN) induce its dephosphorylation (18). Upon stimulation by epidermal growth factor (EGF), cofilin-1 becomes activated through dephosporylation and dissociation from phosphatidylinositol 4,5-bisphosphate (PIP2) in order to reorganize the cytoskeleton for chemiotactic migration (27). Changes on the intracellular $\mathrm{pH}$, regulated by $\mathrm{Na}^{+}-\mathrm{H}^{+}$ exchanger 1 (NHE1), can also affect cofilin-1 activity. When $\mathrm{pH}$ is higher than normal (6.8-7.4), cofilin-1 can be also activated through dissociation from the inhibitory complexes with cortactin and $\mathrm{PIP}_{2}(25,28,29)$.

In the context of cancer metastasis and cell migration, cofilin- 1 is active at the leading edge of migrating cells protrusions and its levels have been studied in various types of cancer (25). In non-small cell lung cancer (NSCLC), high cofilin-1 levels were correlated with lower overall survival rate, cellular invasiveness and resistance to drugs, and particularly, to cisplatin (30-33). Coflin-1 was also found upregulated in breast cancer and its levels correlated with tumor size and stage (34-36). Overexpression of cofilin-1 can predict shorter progression-free survival in advanced ovarian cancer patients, receiving standard therapy (37). Immunohistochemistry studies on prostate tissue sections revealed expression of cofilin- 1 in $70 \%$ of prostate cancer samples, while benign prostate hyperplasia samples were negative for the protein. In the same study, cofilin-1 levels were significantly associated with the Gleason score and the presence of lymph node metastasis (38). Furthermore, proteomic analysis of saliva from patients with head and neck squamous cell carcinoma, revealed significantly increased levels of cofilin-1 compared to the control group (39). Additionally, high expression levels of cofilin-1 were associated with large tumor size, high TNM stage, lymph node metastasis, and decreased overall survival in immunohistochemical studies of patients with squamous cell and adenosquamous carcinoma, and adenocarcinoma of the gallbladder (40). Finally, high levels of cofilin-1 expression compared to normal tissue have also been documented in pancreatic cancer (41) and oral carcinoma (42).

As mentioned above, in our study, the differentially expressed proteins were obtained from the comparison of normal cervical keratinocytes with the three different cervical cancer cell lines. These cervical cancer cell lines differ primarily by the presence or absence and the type of the HPV. Specifically, HeLa is positive for HPV18, $\mathrm{SiHa}$ is positive for HPV16, and C-33A is negative for HPV. These cell lines were carefully chosen for our analysis in order to investigate the differences between the HPV-positive and HPV-negative types of cervical cancers. The availability of the 18 informative differentially expressed proteins (Figure 3 and Table II) revealed from these two-way comparisons among the four cell lines, provide the impetus for further functional studies to dissect the molecular mechanisms that could play a role in the two distinct pathways of cervical carcinogenesis.

Our study is the first to provide an insight into the differences of the total proteome of cervical cancer cell lines in direct comparison to normal cervical keratinocytes. Most of the proteomic studies utilizing cervical cancer cell lines, focus on the differences that occur in the protein expression pattern as an effect of a drug treatment, such as doxorubicin, oxymatrine and cisplatin (43-45), or under stress conditions, like UVB irradiation and hypoxia $(46,47)$, or after the induced and/or inhibited expression of specific genes, as in the cases of HVP16 E6 gene, transgelin-2 and parkin (48-50). Moreover, our group has recently studied the secretome of these cervical cancer cell lines compared to normal cervical keratinocytes (8). Comparative analysis of the secretome revealed 67 differentially expressed proteins, out of which 36 were also identified as differentially expressed in our study. Furthermore, Lin et al. (51) proposed several putative biomarkers for the rare and very aggressive type of neuroendocrine cervical cancer by comparing the proteomic profile of HM-1, a neuroendocrine cervical cancer cell line, to CaSki, ME-180, and HeLa, that exhibit a non-neuroendocrine origin (51). Their study disclosed 82 differentially expressed proteins and further confirmed the differential expression of transgelin, galectin-1 and PGK-1 in all cell lines employing western blotting. Interestingly, transgelin and PGK-1 were also found differentially expressed in our analysis, suggesting a pivotal role of these proteins in cervical pathology.

In conclusion, the proteomic comparison of the three cervical cancer cell lines with normal cervical keratinocytes, revealed novel proteins that are potentially deregulated in cervical cancer and could be further investigated as putative biomarkers and pharmacological targets. Moreover, bioinformatics analysis indicated that these proteins are involved in processes and pathways that are already documented to be active during carcinogenesis, confirming the validity of the proteomics results. The expression trend of cofilin-1, that was found up-regulated in the cancer group, was confirmed by western blot. Although cofilin-1 has been studied thoroughly in the context of various types of cancer, to our knowledge, it has not been studied yet in cervical cancer. Therefore, the up-regulation of the protein in the cancer cell lines we documented, indicates that cofilin-1 could also be overexpressed in cervical cancer biopsies. Nevertheless, confirmation of this hypothesis in a cohort of well-characterized clinical samples of different clinical stages is definitely needed, and could lead to the use of 
cofilin-1 as a valuable marker of either cancerous and/or precancerous lesions of the cervical epithelium.

\section{Acknowledgements}

This study was funded by the Oncology Program of the Central Council of Health of the Ministry of Health, Grant No. 70-3-9209 to Nicholas P. Anagnou, and by the European Union's European Social Fund (ESF) and Greek National Funds through the Program THALIS, under the Operational Program Education and Lifelong Learning of the National Strategic Reference Framework (NSRF), Grant No. 703-11830 to Kalliopi I. Pappa. The authors wish to thank Dr. Tohru Kiyono (National Cancer Centre Research Institute, Tokyo, Japan) for his generous gift of the HCK1T normal cervical cell line.

\section{References}

1 Torre LA, Bray F, Siegel RL, Ferlay J, Lortet-Tieulent J and Jemal A: Global cancer statistics, 2012. CA Cancer J Clin 65: 87-108, 2015.

2 International human papillomavirus reference center on: 20/01/2017. Available from: http://www.hpvcenter.se/index.php

3 Arbyn M, Tommasino M, Depuydt C and Dillner J: Are 20 human papillomavirus types causing cervical cancer? J Pathol 234: 431-435, 2014.

4 de Sanjose S, Quint WG, Alemany L, Geraets DT, Klaustermeier JE, Lloveras B, Tous S, Felix A, Bravo LE, Shin HR, Vallejos CS, de Ruiz PA, Lima MA, Guimera N, Clavero O, Alejo M, LlombartBosch A, Cheng-Yang C, Tatti SA, Kasamatsu E, Iljazovic E, Odida M, Prado R, Seoud M, Grce M, Usubutun A, Jain A, Suarez GA, Lombardi LE, Banjo A, Menendez C, Domingo EJ, Velasco J, Nessa A, Chichareon SC, Qiao YL, Lerma E, Garland SM, Sasagawa T, Ferrera A, Hammouda D, Mariani L, Pelayo A, Steiner I, Oliva E, Meijer CJ, Al-Jassar WF, Cruz E, Wright TC, Puras A, Llave CL, Tzardi M, Agorastos T, Garcia-Barriola V, Clavel C, Ordi J, Andujar M, Castellsague X, Sanchez GI, Nowakowski AM, Bornstein J, Munoz N, Bosch FX, Retrospective International S and Group HPVTTS: Human papillomavirus genotype attribution in invasive cervical cancer: A retrospective cross-sectional worldwide study. Lancet Oncol 11: 1048-1056, 2010.

5 Schiffman M, Doorbar J, Wentzensen N, de Sanjose S, Fakhry C, Monk BJ, Stanley MA and Franceschi S: Carcinogenic human papillomavirus infection. Nat Rev Dis Primers 2: 16086, 2016.

6 Kontostathi G, Zoidakis J, Anagnou NP, Pappa KI, Vlahou A and Makridakis M: Proteomics approaches in cervical cancer: Focus on the discovery of biomarkers for diagnosis and drug treatment monitoring. Expert Rev Proteomics 13: 731-745, 2016.

7 Pappa KI, Polyzos A, Jacob-Hirsch J, Amariglio N, Vlachos GD, Loutradis D and Anagnou NP: Profiling of discrete gynecological cancers reveals novel transcriptional modules and common features shared by other cancer types and embryonic stem cells. PLoS One 10: e0142229, 2015.

8 Kontostathi G, Zoidakis J, Makridakis M, Lygirou V, Mermelekas G, Papadopoulos T, Vougas K, Vlamis-Gardikas A, Drakakis P, Loutradis D, Vlahou A, Anagnou NP and Pappa KI: Cervical cancer cell line secretome highlights the roles of transforming growth factor-beta-induced protein ig-h3, peroxiredoxin-2, and nrf2 on cervical carcinogenesis. Biomed Res Int 2017: 4180703, 2017.
9 Makridakis M, Gagos S, Petrolekas A, Roubelakis MG, Bitsika V, Stravodimos K, Pavlakis K, Anagnou NP, Coleman J and Vlahou A: Chromosomal and proteome analysis of a new t24based cell line model for aggressive bladder cancer. Proteomics 9: 287-298, 2009.

10 Narisawa-Saito M, Handa K, Yugawa T, Ohno S, Fujita M and Kiyono T: Hpv16 e6-mediated stabilization of erbb2 in neoplastic transformation of human cervical keratinocytes. Oncogene 26: 2988-2996, 2007.

11 Yugawa T, Handa K, Narisawa-Saito M, Ohno S, Fujita M and Kiyono T: Regulation of notch1 gene expression by p53 in epithelial cells. Mol Cell Biol 27: 3732-3742, 2007.

12 Wang W, Eddy R and Condeelis J: The cofilin pathway in breast cancer invasion and metastasis. Nat Rev Cancer 7: 429-440, 2007.

13 Condeelis JS, Wyckoff JB, Bailly M, Pestell R, Lawrence D, Backer J and Segall JE: Lamellipodia in invasion. Semin Cancer Biol 11: 119-128, 2001.

14 Dowling P, Meleady P, Dowd A, Henry M, Glynn S and Clynes M: Proteomic analysis of isolated membrane fractions from superinvasive cancer cells. Biochim Biophys Acta 1774: 93-101, 2007.

15 Sidani M, Wessels D, Mouneimne G, Ghosh M, Goswami S, Sarmiento C, Wang W, Kuhl S, El-Sibai M, Backer JM, Eddy R, Soll $\mathrm{D}$ and Condeelis $\mathrm{J}$ : Cofilin determines the migration behavior and turning frequency of metastatic cancer cells. J Cell Biol 179: 777-791, 2007.

16 van Rheenen J, Condeelis J and Glogauer M: A common cofilin activity cycle in invasive tumor cells and inflammatory cells. J Cell Sci 122: 305-311, 2009.

17 Tania N, Prosk E, Condeelis J and Edelstein-Keshet L: A temporal model of cofilin regulation and the early peak of actin barbed ends in invasive tumor cells. Biophys J 100: 1883-1892, 2011.

18 Chang CY, Leu J and Lee YJ: The actin depolymerizing factor (adf)/cofilin signaling pathway and DNA damage responses in cancer. Int J Mol Sci 16: 4095-4120, 2015.

19 Vazquez A, Kamphorst JJ, Markert EK, Schug ZT, Tardito S and Gottlieb E: Cancer metabolism at a glance. J Cell Sci 129: 33673373, 2016.

20 Petrie RJ and Yamada KM: At the leading edge of threedimensional cell migration. J Cell Sci 125: 5917-5926, 2012.

21 Fife CM, McCarroll JA and Kavallaris M: Movers and shakers: Cell cytoskeleton in cancer metastasis. Br J Pharmacol 171: 5507-5523, 2014.

22 Uhlen M: Response to: Should we ignore western blots when selecting antibodies for other applications? Nat Meth 14: 215216, 2017.

23 Nishida E, Maekawa S and Sakai H: Cofilin, a protein in porcine brain that binds to actin filaments and inhibits their interactions with myosin and tropomyosin. Biochemistry 23: 5307-5313, 1984.

24 Elam WA, Kang H and De la Cruz EM: Biophysics of actin filament severing by cofilin. FEBS Lett 587: 1215-1219, 2013.

25 Bravo-Cordero JJ, Magalhaes MA, Eddy RJ, Hodgson L and Condeelis $\mathrm{J}$ : Functions of cofilin in cell locomotion and invasion. Nat Rev Mol Cell Biol 14: 405-415, 2013.

26 Andrianantoandro E and Pollard TD: Mechanism of actin filament turnover by severing and nucleation at different concentrations of adf/cofilin. Mol Cell 24: 13-23, 2006. 
27 van Rheenen J, Song X, van Roosmalen W, Cammer M, Chen X, Desmarais V, Yip SC, Backer JM, Eddy RJ and Condeelis JS: Egf-induced pip2 hydrolysis releases and activates cofilin locally in carcinoma cells. J Cell Biol 179: 1247-1259, 2007.

28 Magalhaes MA, Larson DR, Mader CC, Bravo-Cordero JJ, GilHenn $\mathrm{H}$, Oser $\mathrm{M}$, Chen $\mathrm{X}$, Koleske AJ and Condeelis J: Cortactin phosphorylation regulates cell invasion through a phdependent pathway. J Cell Biol 195: 903-920, 2011.

29 Frantz C, Barreiro G, Dominguez L, Chen X, Eddy R, Condeelis J, Kelly MJ, Jacobson MP and Barber DL: Cofilin is a ph sensor for actin free barbed end formation: Role of phosphoinositide binding. J Cell Biol 183: 865-879, 2008.

30 Muller CB, De Bastiani MA, Becker M, Franca FS, Branco MA, Castro MA and Klamt F: Potential crosstalk between cofilin-1 and egfr pathways in cisplatin resistance of non-small-cell lung cancer. Oncotarget 6: 3531-3539, 2015.

31 Becker M, De Bastiani MA, Muller CB, Markoski MM, Castro MA and Klamt F: High cofilin-1 levels correlate with cisplatin resistance in lung adenocarcinomas. Tumour Biol 35: 1233$1238,2014$.

32 Muller CB, de Barros RL, Castro MA, Lopes FM, Meurer RT, Roehe A, Mazzini G, Ulbrich-Kulczynski JM, Dal-Pizzol F, Fernandes MC, Moreira JC, Xavier LL and Klamt F: Validation of cofilin-1 as a biomarker in non-small cell lung cancer: Application of quantitative method in a retrospective cohort. J Cancer Res Clin Oncol 137: 1309-1316, 2011.

33 Castro MA, Dal-Pizzol F, Zdanov S, Soares M, Muller CB, Lopes FM, Zanotto-Filho A, da Cruz Fernandes M, Moreira JC, Shacter E and Klamt F: Cfl1 expression levels as a prognostic and drug resistance marker in nonsmall cell lung cancer. Cancer 116: 3645-3655, 2010.

34 Shaheed SU, Rustogi N, Scally A, Wilson J, Thygesen H, Loizidou MA, Hadjisavvas A, Hanby A, Speirs V, Loadman P, Linforth R, Kyriacou K and Sutton CW: Identification of stagespecific breast markers using quantitative proteomics. J Proteome Res 12: 5696-5708, 2013.

35 Zhang $\mathrm{Y}$ and Tong X: Expression of the actin-binding proteins indicates that cofilin and fascin are related to breast tumour size. J Int Med Res 38: 1042-1048, 2010.

36 Kabbage M, Chahed K, Hamrita B, Guillier CL, Trimeche M, Remadi S, Hoebeke J and Chouchane L: Protein alterations in infiltrating ductal carcinomas of the breast as detected by nonequilibrium ph gradient electrophoresis and mass spectrometry. J Biomed Biotechnol 2008: 564127, 2008.

37 Nishimura S, Tsuda H, Kataoka F, Arao T, Nomura H, Chiyoda T, Susumu N, Nishio K and Aoki D: Overexpression of cofilin 1 can predict progression-free survival in patients with epithelial ovarian cancer receiving standard therapy. Hum Pathol 42: 516$521,2011$.

$38 \mathrm{Lu} \mathrm{LI}, \mathrm{Fu}$ NI, Luo XU, Li XY and Li XP: Overexpression of cofilin 1 in prostate cancer and the corresponding clinical implications. Oncol Lett 9: 2757-2761, 2015.

39 Dowling P, Wormald R, Meleady P, Henry M, Curran A and Clynes M: Analysis of the saliva proteome from patients with head and neck squamous cell carcinoma reveals differences in abundance levels of proteins associated with tumour progression and metastasis. J Proteomics 71: 168-175, 2008.

40 Yang ZL, Miao X, Xiong L, Zou Q, Yuan Y, Li J, Liang L, Chen $\mathrm{M}$ and Chen S: Cfl1 and arp3 are biomarkers for metastasis and poor prognosis of squamous cell/adenosquamous carcinomas and adenocarcinomas of gallbladder. Cancer Invest 31: 132-139, 2013.

41 Wang Y, Kuramitsu Y, Ueno T, Suzuki N, Yoshino S, Iizuka N, Zhang X, Oka M and Nakamura K: Differential expression of up-regulated cofilin-1 and down-regulated cofilin-2 characteristic of pancreatic cancer tissues. Oncol Rep 26: 15951599,2011

42 Polachini GM, Sobral LM, Mercante AM, Paes-Leme AF, Xavier FC, Henrique T, Guimaraes DM, Vidotto A, Fukuyama EE, Gois-Filho JF, Cury PM, Curioni OA, Michaluart P, Jr., Silva AM, Wunsch-Filho V, Nunes FD, Leopoldino AM and Tajara EH: Proteomic approaches identify members of cofilin pathway involved in oral tumorigenesis. PLoS One 7: e50517, 2012.

43 Filippova M, Filippov V, Williams VM, Zhang K, Kokoza A, Bashkirova $\mathrm{S}$ and Duerksen-Hughes P: Cellular levels of oxidative stress affect the response of cervical cancer cells to chemotherapeutic agents. Biomed Res Int 2014: 574659, 2014.

44 Li M, Su BS, Chang LH, Gao Q, Chen KL, An P, Huang C, Yang $\mathrm{J}$ and $\mathrm{Li} \mathrm{ZF}$ : Oxymatrine induces apoptosis in human cervical cancer cells through guanine nucleotide depletion. Anticancer Drugs 25: 161-173, 2014.

45 Singh M, Bhui K, Singh R and Shukla Y: Tea polyphenols enhance cisplatin chemosensitivity in cervical cancer cells via induction of apoptosis. Life Sci 93: 7-16, 2013.

46 Perluigi M, Giorgi A, Blarzino C, De Marco F, Foppoli C, Di Domenico F, Butterfield DA, Schinina ME, Cini C and Coccia $\mathrm{R}$ : Proteomics analysis of protein expression and specific protein oxidation in human papillomavirus transformed keratinocytes upon UVB irradiation. J Cell Mol Med 13: 1809-1822, 2009.

47 Sorensen BS, Horsman MR, Vorum H, Honore B, Overgaard J and Alsner J: Proteins upregulated by mild and severe hypoxia in squamous cell carcinomas in vitro identified by proteomics. Radiother Oncol 92: 443-449, 2009.

48 Evans W, Filippova M, Filippov V, Bashkirova S, Zhang G, Reeves ME and Duerksen-Hughes P: Overexpression of HPV16 E6* alters $\beta$-integrin and mitochondrial dysfunction pathways in cervical cancer cells. Cancer Genomics Proteomics 13: 259-273, 2016.

49 Yakabe K, Murakami A, Kajimura T, Nishimoto Y, Sueoka K, Sato S, Nawata $S$ and Sugino N: Functional significance of transgelin-2 in uterine cervical squamous cell carcinoma. J Obstet Gynaecol Res 42: 566-572, 2016.

50 Song DG, Kim YS, Jung BC, Rhee KJ and Pan CH: Parkin induces up-regulation of $40 \mathrm{~s}$ ribosomal protein sa and posttranslational modification of cytokeratins 8 and 18 in human cervical cancer cells. Appl Biochem Biotechnol 171: 1630-1638, 2013.

51 Lin LH, Chang SJ, Hu RY, Lin MW, Lin ST, Huang SH, Lyu PC, Chou HC, Lai ZY, Chuang YJ and Chan HL: Biomarker discovery for neuroendocrine cervical cancer. Electrophoresis 35: 2039-2045, 2014. 